\title{
Of words and deeds: Latin American declaratory regionalism, 1994-2014
}

\author{
Nicole Jenne (1) and Francisco Urdinez \\ Pontificia Universidad Católica de Chile
}

\section{Luis Leandro Schenoni \\ University of Notre Dame}

\begin{abstract}
The idea of an integrated Latin American region goes back to the early postindependence period, and yet, in substance, Latin American regionalism has remained far behind its stated aims. The perceived implementation gap has raised the question why policymakers continued to talk about something they appeared to avoid in practice. This article contributes to the debate on Latin America's integration gap by exploring the phenomenon of declaratory regionalism - the practice of referring to the region and its institutions in political speeches. Based on quantitative text analysis of the speeches presidents delivered annually at the UN's General Assembly between 1994 and 2014, we show that this practice has not been uniform. Presidents distinguish between different forms of regionalism, integration and cooperation, and frame the geographical region they refer to accordingly. In motivating presidents to speak about integration as opposed to cooperation, ideology and democratic performance stand out as crucial factors.
\end{abstract}

\section{Introduction}

The idea of Latin American integration is as old as the region's states themselves. In 1824, Simon Bolívar called for the first Pan-American Congress and urged the republics of the Americas to unite (Bushnell 2003, 159). Since then, the concept of integration has changed. While for Bolívar unity was to be achieved in a political federation, today the dominant idea of regional integration in Latin America has come to resemble the experience of the European Union (EU), that is, 'integration' refers to a process in which 'nation states voluntarily mingle, merge and mix with

We would also like to indicate that the statistical results we show can be replicated using the coding and database available at the following Harvard Dataverse link: https://dataverse.harvard. edu/dataset. $x$ html?persistentld $=$ doi $\% 3 \mathrm{~A} 10.7910 \% 2 \mathrm{FDVN} \% 2 \mathrm{FUCWKGC}$

The authors would like to thank the Millennium Nucleus for the Study of Stateness and Democracy in Latin America (RS130002), supported by the Millennium Scientific Initiative of the Ministry of Economy, Development and Tourism of Chile, as well as the Kellogg Institute for International Studies (University of Notre Dame) for their generous support. The Robert Schuman Centre for Advanced Studies (European University Institute) also contributed greatly to this project through the publication of an initial working paper. In addition, the authors would like to acknowledge Olivier Dabène, Andrés Malamud, Detlef Nolte, José Antonio Sanahuja, and Carsten-Andreas Schulz, as well as four patient reviewers, for critical comments that helped to sharpen the arguments put forward here. All remaining errors are our own. 
their neighbours so as to lose the factual attributes of sovereignty' (Haas 1970). In practice, however, policies that have led to the transfer of sovereignty to a supranational regime have been few and far between.

Since the 1960 s, the region has witnessed four waves of regional integration efforts (Dabène 2009). Although each wave was accompanied by fervent enthusiasm, sooner or later these initiatives crumpled. Malamud and Gardini lamented that in the Latin American case 'regionalism understood as "comprehensive economic integration" in a macro-region is losing ground to regionalism understood as "a set of diverse cooperation projects"' (Malamud and Gardini 2012, 117). Another observer even described 'laxity' in implementing formal rules as a founding principle of Latin America's regional identity (Domínguez 2007, 94-97). Most recently, the agenda of regional integration gained prominence again when the early 2000 s saw leftist governments being elected across the region (Sanahuja 2009; Riggirozzi and Tussie 2012). As Latin America's 'Pink Tide' ebbed away, however, a long list of stated aims remains unfulfilled.

Strikingly, Latin America's regionalist discourse appears to have continued unaffected by the repeated setbacks. As one scholar noted, 'after any international dispute a bunch of statesmen rush to declare that "the conflict is over, now it is time for integration"' (Malamud 2013, 20, 4). Moreover, policy-makers have not got tired of reviving the old ideas by reforming existing institutions and creating new ones (Rojas Aravena 2010). The stickiness of Latin America's regionalist idea was also recognized in a recent edited volume that enquires into the Resilience of regionalism in Latin America and the Caribbean (Rivarola Puntigliano and BriceñoRuiz 2013). The editors argue that Latin America's discourse-heavy regionalism-short-in-delivering is best described as a 'cultural-identity space' driven by the quest for emancipation (Dabène 2009). Other authors have come to similar conclusions stating that Latin American regionalism serves a ceremonial function in diplomacy (Montecinos 1996) or provides an ideational dimension bringing the regional states together (Rivarola Puntigliano and Briceño-Ruiz 2013). However, these arguments lump together different forms and types of regionalism and imply that regionalist discourse has persisted equally across time and space; two generalizations that appear problematic when one considers Latin America's regional institutional conglomerate of 'coexisting and competing projects with fuzzy boundaries' (Tussie 2009, 170).

First, regionalism can take different forms of either cooperation or integration. 'Cooperation' is less demanding and refers to policy coordination broadly defined, either in specific issue areas or in entire policy fields. Cooperation can be spontaneous and temporary or can result in concerted action over extended periods of time. In any case, however, it is different from 'integration', which entails a transfer of sovereignty away from the state (Haas 1970; Nye 1968). This definition is reflective of the political realm, but it is implicit also in Bela Balassa's classical model of economic integration, which proceeds from preferential trade agreements in five steps to complete economic integration (Balassa 1967). Already at step three, the transition from a customs union to a common market, some degree of political integration becomes necessary. At the very least, further integration towards the fourth step, economic union, is impossible without the transfer of sovereignty, for instance to a central bank. Yet, given that no single Latin American institution has been endowed with wide-ranging competences, 
it is worth asking whether policy-makers have kept talking about 'integration' or rather have used the more realistic term 'cooperation' when speaking about regional relations.

Secondly, regions are socially constructed and the 'oversupply of integration initiatives' (Rojas Aravena 2013, 159) renders it far from self-evident which region Latin American countries see themselves as being part of: Latin America, South America, or one of the hemisphere's other sub-regions, such as the Andean region or Central America? Against this backdrop, this article seeks to advance our understanding of Latin America's declaratory regionalism by addressing two questions: what are the frames policy-makers use when referring to the region in political speeches, and how can we explain their choices?

To answer these questions, we analyse the presidential speeches of 19 Latin American countries delivered at the annual United Nations General Assembly (UNGA) meetings during 1994-2014. ${ }^{1}$ Our data-set comprises 399 speeches, each of which has on average 2400 words. The analysis lends strong support to the claim that the words 'integration' and 'cooperation' are not used interchangeably. ${ }^{2}$ Although both terms are used in the same speeches, presidents tend to use them in different contexts. First, leftist presidents speak more about 'integration' while presidents on the right of the political spectre mainly refer to 'cooperation'. This finding holds for the period of the 1990s' open regionalism and for the subsequent Pink Tide alike. Furthermore, we find a more frequent use of the term 'integration' when levels of democracy are higher.

Why should we be concerned with regionalist talk if in reality regionalism has remained shallow? It is important to note that we are concerned neither with actual regionalization processes nor with their outcome, but rather with the practice of regionalist discourse (Jenne and Schenoni 2015). Such declaratory regionalism is worth analysing because it creates what Hill called a 'capabilities-expectations gap' (Hill 1993). Hill found such a gap between "what is expected and what can be achieved' in the case of the European Community in the early 1990s as a result of capabilities having been 'talked up' (ibid.). Following Hill, the unfulfilled expectations presented the European countries with 'difficult choices and experiences' (ibid., 326) that were not only 'clearly unsatisfactory' but also 'dangerous' (ibid., 306). Our findings allow us to specify under which conditions expectations have been talked up. Although it is beyond the scope of the article to investigate the reasons for Latin America's integration gap, further research may start from here taking into account that 'integration' is a more frequent referent for leftist governments in more democratic countries.

The article proceeds in four parts. First, we discuss our data and justify the use of UNGA speeches for the purpose of this study. The second section presents descriptive statistics about what presidents talk about when they refer to their region. In the third section we ask why presidents choose to use particular frames of reference in their regionalist discourse. After developing different count models for regression analysis based on the literature on regional integration and Latin American regionalism, we discuss our results. The final section concludes.

1 These include Argentina, Bolivia, Brazil, Chile, Colombia, Costa Rica, Cuba, Dominican Republic, Ecuador, El Salvador, Guatemala, Honduras, Mexico, Nicaragua, Panama, Paraguay, Peru, Uruguay and Venezuela.

${ }^{2}$ For contending views see Sanahuja $(2007,31)$ and an early manifestation from Nye $(1968,856)$. 
Table 1. Terms identified in the content analysis

\begin{tabular}{ll}
\hline & \multicolumn{1}{c}{ Selected terms } \\
\hline Region and sub-region & $\begin{array}{l}\text { Andean region; Caribbean; hemisphere; Americas; Latin } \\
\text { America; South America }\end{array}$ \\
Regional organization & $\begin{array}{l}\text { ALBA; CAN; Mercosur; OAS (Organization of American } \\
\text { States); UNASUR }\end{array}$ \\
Type of regionalism & Integration; cooperation \\
\hline
\end{tabular}

\section{Of words and deeds: measuring declaratory regionalism}

Making statements is a relatively cost-free exercise in material terms and may be considered a habitual practice of state leaders, thus not meriting further attention. Yet, making speeches is not free of charge. Talk creates expectations domestically and internationally that condition future action and provide benchmarks against which a government's achievements can be measured, especially in prominent fora such as the UNGA. Thus, as Hill has argued, the existence of unfulfilled expectations is detrimental to the relevant actor's credibility (Hill 1993, 326, 306, 315). Constructivists go further still when they claim that highly formal policy statements, as declarations of intent, are policies (Onuf 2001). In this line, they have claimed that rhetoric action 'entrapped' European states into the eastern enlargement and integration process by legitimizing the idea of a pan-European community as the appropriate standard for the region (Schimmelfennig 2001).

For the purpose of analysing regionalism in its declaratory dimension we do not need to go so far as to argue that statements are policies. Neither do we use statements as a proxy for foreign policy preferences, although other studies have used voting behaviour at the UNGA as an indicator of state preferences. ${ }^{3}$ Our initial premise is less demanding, holding merely that statements are not made randomly (we support this claim empirically below), and that therefore speeches lend themselves to analysis. Even if one accuses policy-makers of lying, knowing who says what in the region is still relevant to understanding the international politics of Latin America, since presidents are likely to lie not for individual gain but in the service of the national interest (Schimmelfennig 2001).

Our measure of declaratory regionalism is the number of references to the region that were made in one single speech at the UNGA, which creates a country-year unit of analysis. We count as reference to the region all words that are shown in Table 1 and words with the same stem but a different suffix, for example, 'region' /'regional', 'Latin American'/'Latin-Americanism', etc.4

Although the UNGA is not a forum with a primarily regional audience, the frequency with which Latin American presidents have chosen to mention their region in their annual speeches shows that they have considered this occasion as relevant to speaking about regional topics. Between 1994 and 2014, presidential

${ }^{3}$ On the use of the data see Voeten, Strezhnev, and Bailey (2009); for a well-known study see Kim and Russett (1996).

4 The speeches were retrieved from the United Nations Bibliographic Information System (http://unbisnet.un.org/). All words were identified and counted using WordStat. We reviewed all references to 'integration' and 'cooperation' manually to include only those referring to regional cooperation and integration. Thus, phrases such as 'The system of human rights protection should be revised, particularly in the field of family, children, education and international cooperation' (from the Uruguayan speech, 1999) were not included. 
speeches contained on average three references to the region. Generally, content analysis of speeches is a technique that can handle a large amount of unstructured data (Mearsheimer 2010,29) and so allows us to increase the level of comparability across time and countries. The technique is unobtrusive in the sense that presidents were not asked to respond to a set of predetermined questions or to take a position towards regionalism per se. Thus, we can discard the effect of social desirability biases introduced by a researcher.

Moreover, compared with other types of declarations and statements, presidential addresses at the UN bear two important advantages. First, these syntheses of foreign policy priorities are directly attributable to the central decision-making authority and therefore constitute an authoritative source of declaratory regionalism. As elsewhere in the world, in Latin America the executive branch of government is generally the main actor in defining foreign policy strategies, but compared with other democracies Latin American presidents have exceptionally wide-ranging competences in this (and other) policy areas (Krippendorff 2004; Shugart and Carey 1992). The region's 'summitry' - by which presidents undertake important international negotiations tête-à-tête in highly exclusive and rather loosely institutionalized contexts-is illustrative of presidents' influence in foreign policy-making (O'Donnell 1994, Feinberg 2006). Under these circumstances, presidents become the central actors deciding whether to use or to avoid declaratory regionalism.

At the UN, presidents use the annual speeches to outline the main foreign policy objectives of the incumbent administration. Of all speeches in our data-set, almost two-thirds were delivered by presidents themselves. Thirty-six per cent of all speeches were delivered by vice presidents, foreign ministers or other officials, yet these too were pronounced in the name of the head of state.

The second methodological advantage of using the annual speeches at the UNGA rather than statements made in national or regional fora is the relative neutrality of their context. Presidents may say different things depending on their audience and the moment in time a statement is made. Such potential problems of comparability can be minimalized by holding these conditions stable, as is the case in the UNGA opening sessions that take place during September each year. Since the speeches are addressed to other governments but also broadcast to both local and global audiences, the occasion provides an exceptional opportunity for presidents to use declaratory regionalism as both a domestic and a foreign policy tool. The relative indeterminateness of the target audience dilutes potential biases that are likely to be present in speeches delivered in other fora such as regional summits and which contain references to the region almost by default. Thus, by analysing the yearly speeches at the UNGA, it is possible to obtain a broad picture of Latin America's declaratory regionalism over time, which is comparable across countries and years. To the best of our knowledge, for the purpose at hand, this is the first research article to take advantage of the data that are publicly available.

Before we describe Latin America's declaratory regionalism, two caveats are in order. First, a problem common to speech analysis is the fact that some addresses are simply lengthier than others. At the UNGA, Argentina's Fernando de la Rúa performed the shortest intervention with a 695-word speech in 2000, while Mexico's President Felipe Calderón gave the longest speech consisting of 5918 words in 2012. Plain verbosity may therefore be mistaken for an interest in the region, a problem that is linked to a second, arguably more important 
limitation of our analysis, which is neglect of the context in which a statement is made. In order to minimize the problem, we revised all references to 'integration' / 'cooperation' individually, excluding references such as 'development cooperation' that do not specifically concern regional integration/cooperation. To understand these nuances, further research and the use of other methods will be required. In this article, we merely take a first step in describing Latin America's declaratory regionalism and narrow our contribution to explaining under which conditions particular frames are used.

\section{Declaratory regionalism: who says what?}

Based on Table 1, we distinguish three types of frames of declaratory regionalism: distinct geographical regions and sub-regions, regional organizations and the type of regionalism, which may be cooperation (policy coordination) or integration (transfer of sovereignty). This section describes the combined use of references to these frames in the UNGA speeches across countries and time, before it deals with each of the different types individually. First, however, it is necessary to contextualize Latin America's regional project. Although we are not concerned with regionalism in practice, the changes that occurred during the study period need to be taken into consideration when analysing the references made to it in political speeches.

Scholars generally agree that between 1994 and 2014 Latin American regionalism underwent a shift from Washington-consensus-based 'open regionalism' towards a new post-liberal (Sanahuja 2009) or post-hegemonic (Riggirozzi and Tussie 2012) regionalism. Economically, this entailed the re-orientation of development models away from market liberalization towards more inclusive forms of human development. In political terms, post-hegemonic regionalism meant the search for greater autonomy from the United States (US) in commerce and financial policy-making and generally. The following paragraphs show that these shifts are represented in the frames used in declaratory regionalism, but, as we shall argue subsequently, both integration and cooperation remained important core concepts for Latin American presidents in the post-liberal era.

Figure 1 shows the frequency of mentioning the region and its institutions in presidential speeches: the countries with the most vocal regionalist discourse were not the same during the period of open regionalism and after (see Figure 1).

As Figure 1 shows, the countries that heralded a more liberal understanding of regionalism - for example, Brazil, Chile, Paraguay and Panama-were the more vociferous during the first period (1994-2003), while post-liberal regionalism brought to the forefront of declaratory regionalism four out of the five countries of the Bolivarian Alliance for the Peoples of Our America (ALBA)-Ecuador, Venezuela, Cuba and Nicaragua. In line with the shift in the overall frequency of declaratory regionalism, our data also show differences in the use of frames regarding the different geographical regions.

Figure 2 shows that presidential speeches evoked different regional conceptualizations specified as the following macro-regions: South America, Central America, Latin America and the American Hemisphere/Continent. Membership in different institutions that bring together the countries of each of these regions is not exclusive and often overlaps (Malamud and Gardini 2012, 122). However, 


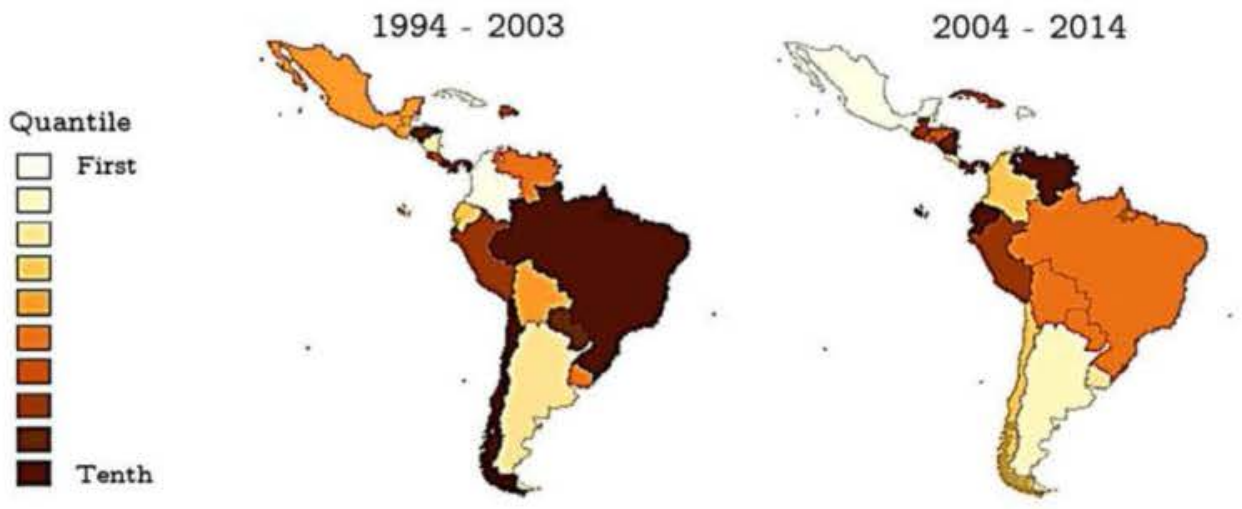

Figure 1. Number of references to regionalism by country

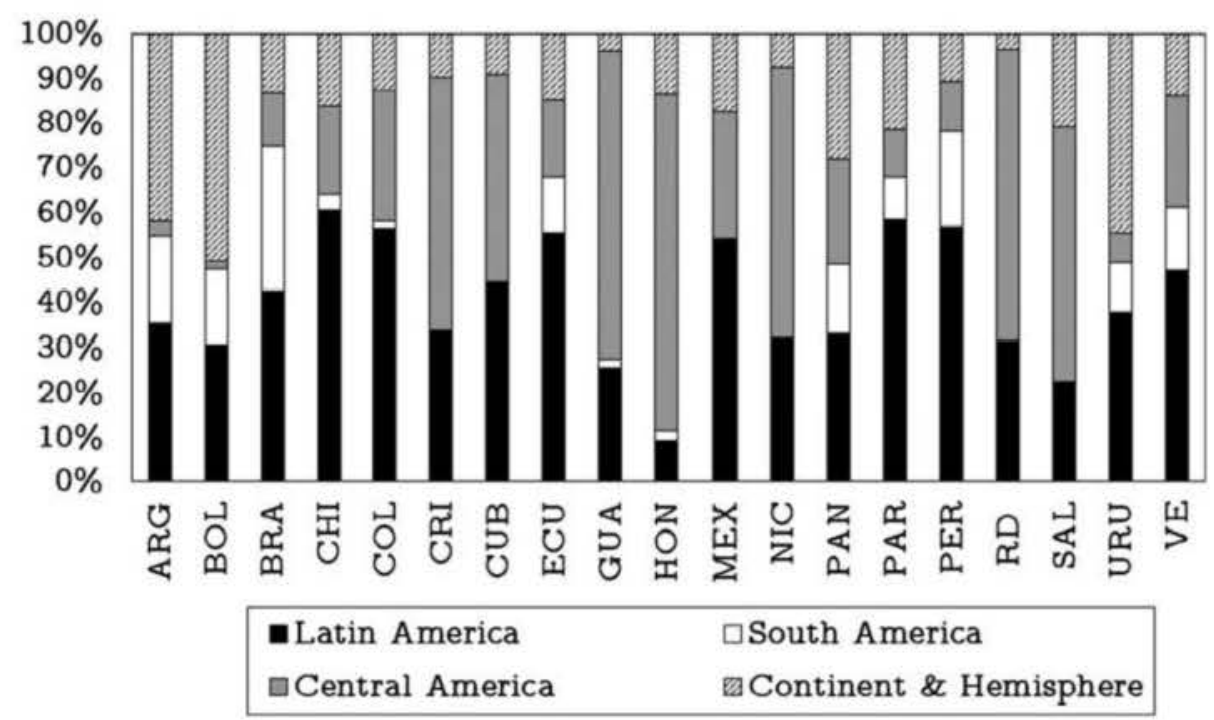

Figure 2. Regional sub-regions by country (as a percentage)

reference to any one region carries a different political message. Framing the region as the 'hemisphere' highlights the leading role of the United States (Legler 2013, 334). Other countries such as Brazil, Latin America's biggest country and largest economy, may prefer evoking sub-regional concepts (including for that matter South America) within which they play a more influential role (Onuki, Mouron and Urdinez, 2016). Central American countries may pursue a similar strategy 'excluding' the United States from the region. The framing of Latin America, on the other hand, can be seen as the best choice of secondary powers such as Argentina or Mexico to simultaneously counter-balance the diplomatic legitimization strategies of the US and Brazil.

As shown in Figure 2, Brazilian presidents referred almost twice as often to South America as did any other government. This reflects the Brazilian origin of 


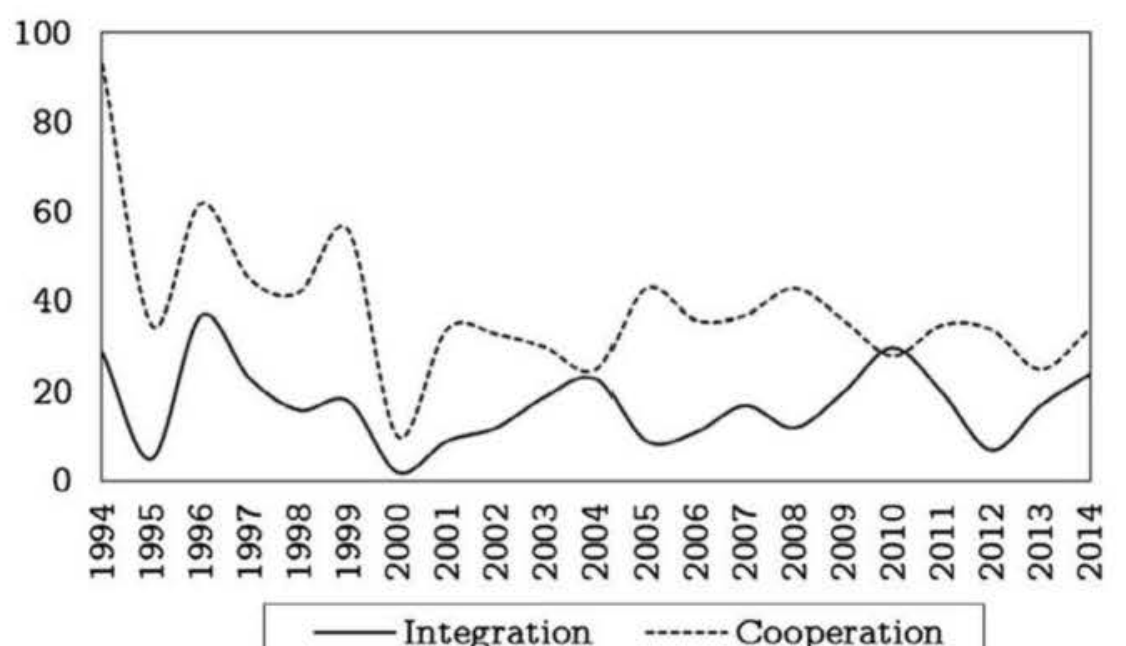

Figure 3. References to integration and cooperation in time

the concept and Brasilia's interest in promoting the sub-region to position itself as the central hub of international cooperation (Burges 2015; Lima 2013; Teixeira 2012). At the opposite side are Colombian and Chilean presidents, who almost never referred to South America in their statements, most likely as a way to counter Brazil's quest for sub-regional influence, as has been noted by several observers (Flemes and Wehner 2015). Although the contrast is less stark in other cases, the tendencies nevertheless reflect foreign policy preferences as discussed in the relevant literature. Venezuela, for instance, tended to avoid the concept of South America as a means of discursive contestation and initially preferred 'Latin America'. Later on, however, former president Hugo Chávez embraced the Brazilian concept (Chodor and McCarthy-Jones 2013) and incorporated it into his speeches. The same can be said of Argentina, Bolivia and Uruguay, where references to hemispheric and Pan-American relations during the 1990s were replaced almost entirely by references to South America in the 2000 s, leading to the mixed output in Figure 2.

What could be labelled a 'paradigm shift' in Latin American regionalism has led some observers to argue that the ' $\mathrm{t}] \mathrm{he}$ conception of integration/regionalism in terms of trade is deeply associated with the notion of "open regionalism"' (Grugel and Riggirozzi 2012, 2), thus linking the term 'integration' to the very agenda that post-liberal regionalism has sought to overcome. Accordingly, we should see presidents in the post-liberal era talking less about integration, a trend that cannot be confirmed by our data, as shown in Figure 3. We set the cut-off point when the orthodox neoliberal economic model was finally abandoned in 2004, the year the US-led negotiations on a Free Trade Area of the Americas (FTAA) were stopped. Since then, the word 'integration' has been used between nine and 30 times in the yearly UNGA speeches, with no discernible trend. ${ }^{5}$

${ }^{5}$ The year 2000 needs to be seen as an exception given that all speeches revolved around the establishment of the Millennium Development Goals by the UN. 

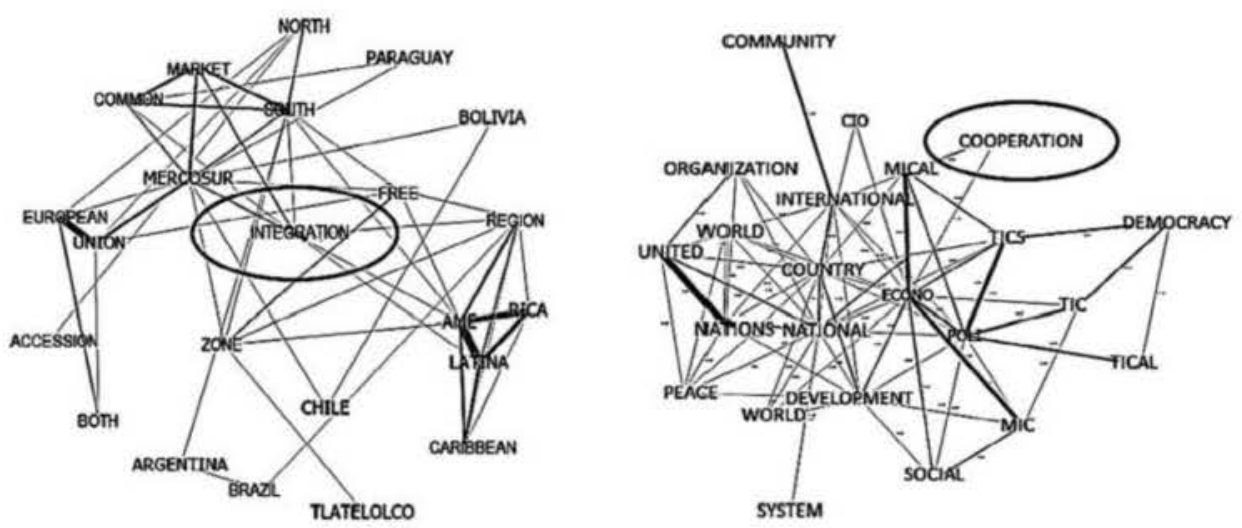

Figures 4. Word clusters
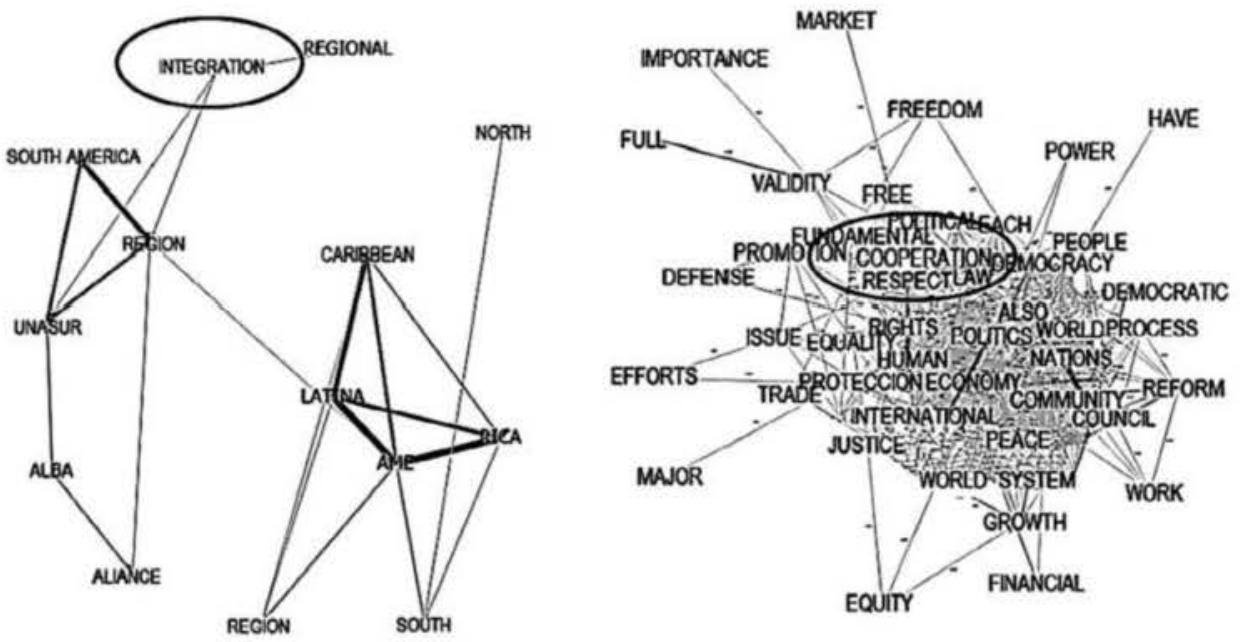

Figures 5. Word clusters

Interestingly, the curve of the use of the word 'cooperation' correlates more closely to the use of 'integration' during the period of open regionalism. Yet, after 2004 too, the relation is not clearly anti-cyclical, indicating that the two terms were not used as substitutes but tended to be used in conjunction. These numbers suggest that on the aggregate regional level the core ideas of integration and cooperation remained similarly important references both during open regionalism and in its aftermath, although their content may have differed over time.

To probe this point further, we examined the context in which the terms 'integration' and 'cooperation' were used in relation to other words. Figures 4 and 5 show the most frequent associations of words with 'integration' and 'cooperation', respectively, during the time of open regionalism and during the post-liberal period. For a word to be associated with either of the terms, it had to appear within the same paragraph, these being typically no longer than three sentences 
in the transcripts of UNGA speeches. The closeness of association is measured by a Jaccard coefficient using WordStat and is reflected in the distance from the words 'integration' and 'cooperation'. In addition, the figures show whether the associated words are related, thicker lines meaning a stronger association.

Two conclusions can be drawn from comparing the word clusters for the periods 1994-2004 and 2004-2014. First, the concept of 'cooperation' clearly broadened over time to become associated with a larger number of areas including defence, finance and the rule of law, amongst others. Second, contrary to the claim that Latin American regionalism turned away from the (Washington-consensus-associated) term of 'integration', the associated terms in Figure 5 show that integration remained an important concept for post-liberal Latin and South American regionalism. Taken together, our data suggest that, although there were changes in how policy-makers thought about integration and cooperation and about how these were best achieved, the core ideas of 'integration' and 'cooperation' remained relevant referents for Latin American regionalism. This sets the basis for the analysis in the next section, but, before proceeding, it is worth highlighting that our conclusion is in line with less radical readings of the development of Latin America's regionalist project, which point to continuities rather than sweeping change.

First, as one of the advocates of the paradigm shift argument himself points out, open regionalism was not merely about economic integration but inherently political, as the liberal agenda simultaneously sought to fill governance spaces in areas such as regional security and migration, amongst others (Sanahuja 2012). Second, new organizations such as the Union of South American Nations (UNASUR) and the Bolivarian Alliance for the Peoples of Our America-People's Trade Treaty (ALBA$\mathrm{TCP}$ ) have not been bestowed with independent competences to promote inclusive development (Dabène 2009; Serbin 2011, 17:6); and, third, amongst them was also the Pacific Alliance, which, since its creation in 2011, has been a prime example of market liberalism with no agenda of political integration (Malamud 2013, 20:5).

Having established the concepts of integration and cooperation as valid categories in political speeches, the following section asks under which conditions presidents enact these utterances.

\section{What drives the discursive integration of Latin America?}

To shed light on the circumstances under which presidents talk about regional integration and the less demanding form of regional cooperation, respectively, we constructed a panel of declaratory regionalism at the UNGA for 19 Latin American countries for the period from 1994 to 2014. Two separate models seek to explain references to integration and cooperation by country-years.

Our independent variables can be divided into two sets of factors. The first set of independent variables accounts for the socio-political conditions in a given country and captures factors that are highlighted as drivers of integration in the literature on Latin American regionalism and regional integration theory. First, we account for the ideology of the president. Ernst Haas, the founding father of neo-functionalist regional integration theory, was reluctant to concede any role to ideology when writing on the European Communities in the 1950s. He considered ideology to be 'merely a mood, an ambiance that remains compatible with 
the attenuated national consciousness' in Europe (Haas 1958, xxix). Within the discipline of international relations (IR), the end of the Cold War discredited theorizing ideology further. However, in Latin America the regional patria grande (the greater motherland) has traditionally been an important referent for leftist ideology and culture. The progressive electorate has supported regionalism as part of an anti-US, anti-capitalist intellectual tradition (Corrales and Feinberg 1999). As Olivier Dabène has written, 'the leftist discourse is ambiguous to the extent that it uses integration as an instrument to defend the sovereignty of these countries against the threat of imperialism' (Dabène 2009, 367). Regardless of the fact that Latin America's left has failed to build strong regional institutions-indeed, the only regional integration scheme initiated by the left was ALBA - to explain declaratory regionalism we therefore expect ideology to increase integrationist talk at the UNGA.

To operationalize the ideology of presidents, we combined three different measures into a new variable that ranges from 1 (extremely left) to 7 (extremely right). The 1-7 scale is used by Merke and Reynoso (2016), who carried out expert surveys to classify the ideological position of Latin American presidents. Since experts' assessments may be problematic, we further consulted the data from Murillo et al (2010) and Levitsky and Roberts (2013), whose studies define as 'left' 'political actors who seek, as a central programmatic objective, to reduce social and economic inequalities' (5, emphasis in original). Both data-sets have limitations, however. Murillo et al cover all countries included in our study only up to 2008; Levitsky and Roberts (2013) cover all years but for a limited number of countries. Moreover, their coding is minimalistic in the sense that it is a dichotomous variable that assumes 1 when the president is leftist and 0 otherwise.

After rescaling the data from Murillo et al on to a 1-7 scale, it is possible to see that the measure closely correlates with Merke and Reynoso's $(0.90)$. When transformed into a dummy variable (with the threshold set at 3.5), both data-sets have a correlation with Levitsky and Roberts of 0.81 . Being confident that the three datasets are an accurate measure of the ideological position of Latin American presidents, we calculated the mean of Merke and Reynoso and the rescaled version of Murillo et al and used this measure as our proxy for ideology of the president.

In addition, we include economic growth as a proxy for the expansion of economic activity. Both functionalist theories of regional integration (Haas 1970; Schmitter 1970) and Moravzcik's influential liberal intergovernmentalism (Moravcsik 1993) put the expansion of production and trade at the heart of the integration process. While the relation between economic performance and actual integration is beyond our concern, we are interested in whether, as a result of economic growth, domestic demands for greater access to foreign (including regional) markets pressure governments into advocating integration. Solingen (1998) has shown how emerging economic actors can foster pro-integration coalitions in regions other than Europe, including in the American Southern Cone, and we therefore expect economic growth to lead to more references to integration as presidents seek to satisfy domestic constituencies.

Conversely, we expect economic slump to increase presidents' references to 'cooperation'. Latin American governments typically rely on outputlegitimacy, with the effect that economic crises often translate unhampered into

${ }^{6}$ We thank one of the reviewers for pointing this out. 
socio-political crises (Pérez Liñan 2010). Domestically embattled governments are highly unlikely to lead integration initiatives and may even retreat from them, as we see in the case of Brazil, which was Latin America's most likely leader of regional integration with the potential to bear the costs of integration (Jenne 2015; Malamud, 2005; Schenoni 2017). Cooperation, on the other hand, entails fewer costs and was widely used by Latin American governments in the past to bolster their legitimacy externally when faced with internal economic crises (Grugel and Riggirozzi 2007,99 ). The yearly economic growth rates were retrieved from the World Bank Data indicators.

The third variable of countries' socio-political context included in the models is democratic performance. Here, we build on the well-established insight that democracy is a precondition for successful integration (Deutsch 1957; Hurrell 1998, 254; Schmitter 1995). Debate about this can be seen as an appendage to discussion of the democratic peace theory, which is especially contested in the Latin American context (Martín 2006, 118-124; Simmons 2002). Scholars disagree over how best to explain the correlation between democracy and integration, some pointing to incentive structures created by domestic institutions (Mansfield et al 2008), while others highlight shared value and belief systems (Inglehart 1997). Regardless of the mechanism at work, we expect the number of references to 'integration' to increase with higher scores of democratic performance, for which we use the standard measure of the Polity IV data project (Marshall et al 2002).

In addition, a state's external geopolitical environment is likely to influence presidents' rhetoric in international fora such as the UNGA. The dominant realist school of IR predicts cooperation between states in the face of external threats, which in the case of Latin America stem almost exclusively from their immediate neighbours. Governments are unlikely to promote regional integration when they are in conflict with a neighbouring state; instead we expect presidents to speak about cooperation in situations of interstate dispute with the same frequency or even more so than in times of amicable relations. Disputes between Latin American states have seldom disrupted diplomatic relations or, worse, escalated into armed conflict (Martín 2006). Rather, governments have turned to the region for help to mediate quarrels formally or informally (Domínguez 2003). At the very least, disputes have prompted governments to call for enhanced cooperation (Merke 2011), which leads us to expect a higher frequency of the use of the term 'cooperation' in years in which states experienced interstate dispute. To measure whether a state faced external conflict, we rely on the Militarized Interstate Dispute (MID) data of Palmer et al (2015), who record cases of conflict 'in which the threat, display or use of military force short of war by one member state is explicitly directed towards the government, official representatives, official forces, property, or territory of another state' (Jones et al 1996, 163). In the sample, 14 per cent of all country-year dyads had an MID.

Lastly, the models include a variable for electoral years to control for the effect of presidents using the UNGA as a platform to gain support for upcoming national elections. Thus, Argentina's Nestor Kirchner for instance compared himself in the election year 2007 with other candidates by saying, 'In our policy, regional integration is a priority.' The year is calculated as 12 months from the UNGA annual opening session.

The second set comprises references to Latin America's different geographical regions and regional organizations. With these variables we seek to control for 
whether the term 'integration' was more often used by members of an organization that has explicit goals to integrate. The Southern Common Market (Mercosur), for instance, has explicitly promoted economic integration. On the other hand, UNASUR has made little headway in integrating its members either economically or politically. Nevertheless, because UNASUR was the first flagship project of South America's post-liberal regionalism and as such received widespread support from the Pink Tide governments, we can expect that being a member of UNASUR increased the use of the term 'integration' as well. Following the same logic, we expect policy-makers to speak about 'integration' more often when they refer to Central America, South America or Latin America than when presidents speak about the 'hemisphere'. Although these variables often show the significance and sign that we expect, they are included merely as controls in our models.

\section{Statistical model}

A count econometric model that considers how many times something has happened is best suited for our data. ${ }^{7}$ The choice of the best-fit count model depends on two sets of questions: (a) How is our outcome variable distributed? How does the variance compare with the mean? and (b) Does the outcome variable contain zeroes?

A Poisson regression model (PRM), the most common count model, works with a strong assumption that the conditional variance in the dependent variable equals the conditional mean. If this is not the case, negative binomial regression (NBRM) can be used for over-dispersed count data, that is, when the conditional variance exceeds the conditional mean. In our data, however, the dependent variables (references to 'integration' and 'cooperation' in a speech) contain zeroes, which excludes the possibility of using truncated specifications. Moreover, a likelihood ratio test showed that our dependent variables are not overly dispersed. This suggests that the best specification is a Poisson model, to which we added robust standard errors and yearly fixed effects. A correlation matrix of the independent variables shows that we can rule out problems of multicolinearity (see Table A in the Appendix).

\section{Results}

Table 2 provides the coefficients expressed as percentage changes in the expected count. Presented in this way, the results are easily comparable when contrasting the two types of declaratory regionalism, integration and cooperation. Models 1 , 2 and 3 explore the relation between the independent variables and the use of the word 'integration' in speeches; models 4,5 , and 6 repeat the same with regards to the use of the word 'cooperation'.

Models 1 and 4 include the least variables, testing these without the use of geographic regional frames and fixed effects for regional organizations. Models 2 and

${ }^{7}$ Few IR scholars have used count models. The most frequently used statistical model, linear regression, makes the problematic assumption that underlying continuous processes generate observations that are also continuous. The true relationship in our dependent variables is not linear, and a linear approximation would not, in most cases, even be a reasonable working assumption (King $1988,845)$. 
Table 2. Percentage change in expected count for mentions of 'integration' in presidential speeches at UNGA

\begin{tabular}{|c|c|c|c|c|c|c|}
\hline & \multicolumn{3}{|c|}{ Integration } & \multicolumn{3}{|c|}{ Cooperation } \\
\hline & Model 1 & Model 2 & Model 3 & Model 4 & Model 5 & Model 6 \\
\hline \multirow{2}{*}{$\begin{array}{l}\text { Economic } \\
\text { growth }(\%)\end{array}$} & 3.4 & 2.5 & 2.5 & -0.7 & -1.1 & -2 \\
\hline & $(0.205)$ & $(0.387)$ & $(0.368)$ & $(0.677)$ & $(0.544)$ & $(0.366)$ \\
\hline \multirow{2}{*}{$\begin{array}{l}\text { President's } \\
\text { ideology }(\%)\end{array}$} & $-16^{*}$ & $-13.5^{*}$ & $-13^{*}$ & $20^{* * *}$ & $18.5^{* * *}$ & $18^{* * *}$ \\
\hline & $(0.013)$ & $(0.023)$ & $(0.036)$ & $(0.000)$ & $(0.000)$ & $(0.000)$ \\
\hline \multirow[t]{2}{*}{ Electoral year (\%) } & 1.4 & -4 & -3 & -5 & -6 & -6 \\
\hline & $(0.939)$ & 0.830 & $(0.893)$ & $(0.665)$ & $(0.633)$ & $(0.622)$ \\
\hline \multirow{2}{*}{$\begin{array}{l}\text { Democratic } \\
\text { performance }(\%)\end{array}$} & $11.3^{* * *}$ & $9^{* * *}$ & $8^{* *}$ & $-3^{*}$ & $-3^{*}$ & $-3.5^{*}$ \\
\hline & $(0.000)$ & 0.000 & $(0.003)$ & $(0.035)$ & $(0.043)$ & $(0.023)$ \\
\hline \multirow{2}{*}{$\begin{array}{l}\text { Interstate } \\
\text { dispute (\%) }\end{array}$} & -20 & -33 & -44 & -6.5 & -6 & -12 \\
\hline & $(0.431)$ & 0.131 & $(0.060)$ & $(0.71)$ & $(0.743)$ & $(0.477)$ \\
\hline \multirow{2}{*}{$\begin{array}{l}\text { GDP per } \\
\text { capita }(\%)\end{array}$} & 0.008 * & $0.001 *$ & 0.000 & 0.000 & 0.000 & 0.000 \\
\hline & $(0.013)$ & $(0.012)$ & $(0.075)$ & $(0.77)$ & $(0.979)$ & $(0.510)$ \\
\hline \multirow[t]{2}{*}{ Population (\%) } & 0.1 & 0.01 & -0.1 & 0.1 & 0.2 & 0.3 * \\
\hline & $(0.646)$ & 0.958 & $(0.643)$ & $(0.168)$ & $(0.069)$ & $(0.016)$ \\
\hline \multirow[t]{2}{*}{ Pink Tide year (\%) } & 58 & $184^{*}$ & $170^{*}$ & $-72 * *$ & $-77 * *$ & $-76^{* *}$ \\
\hline & $(0.217)$ & 0.027 & $(0.032)$ & $(0.001)$ & $(0.004)$ & $(0.005)$ \\
\hline \multirow{2}{*}{$\begin{array}{l}\text { References to } \\
\text { 'cooperation' (\%) }\end{array}$} & $14^{* * *}$ & $11^{* * *}$ & $10^{* * *}$ & - & - & - \\
\hline & $(0.000)$ & $(0.000)$ & $(0.000)$ & - & - & - \\
\hline \multirow{2}{*}{$\begin{array}{l}\text { References to } \\
\text { 'integration' (\%) }\end{array}$} & - & - & - & $15.5^{* * *}$ & $14^{* * *}$ & $12^{* * *}$ \\
\hline & - & - & - & $(0.000)$ & $(0.000)$ & $(0.000)$ \\
\hline \multirow{2}{*}{$\begin{array}{l}\text { References to } \\
\text { 'hemisphere' (\%) }\end{array}$} & - & 3 & 2.2 & - & 26 & 31 * \\
\hline & - & $(0.816)$ & $(0.841)$ & - & $(0.062)$ & $(0.037)$ \\
\hline \multirow{2}{*}{$\begin{array}{l}\text { References to } \\
\text { Central } \\
\text { America (\%) }\end{array}$} & - & 3.5 & $12^{* * *}$ & - & 4 & 5 \\
\hline & - & $(0.267)$ & $(0.000)$ & - & $(0.104)$ & $(0.07)$ \\
\hline \multirow{2}{*}{$\begin{array}{l}\text { References to } \\
\text { Latin America (\%) }\end{array}$} & - & $11.5^{* *}$ & $9^{* *}$ & - & 1.3 & 1.5 \\
\hline & - & $(0.002)$ & $(0.008)$ & - & $(0.587)$ & $(0.499)$ \\
\hline \multirow{2}{*}{$\begin{array}{l}\text { References to } \\
\text { South America (\%) }\end{array}$} & - & $17^{*}$ & $15 *$ & - & 1.4 & 0.3 \\
\hline & - & $(0.022)$ & $(0.017)$ & - & $(0.573)$ & $(0.899)$ \\
\hline
\end{tabular}


Table 2. (Continued)

\begin{tabular}{|c|c|c|c|c|c|c|}
\hline & \multicolumn{3}{|c|}{ Integration } & \multicolumn{3}{|c|}{ Cooperation } \\
\hline & Model 1 & Model 2 & Model 3 & Model 4 & Model 5 & Model 6 \\
\hline \multirow{2}{*}{$\begin{array}{l}\text { Mercosur } \\
\text { members (\%) }\end{array}$} & - & - & $67^{*}$ & - & - & -9 \\
\hline & - & - & $(0.026)$ & - & - & $(0.522)$ \\
\hline \multirow[t]{2}{*}{ CAN members (\%) } & - & - & $103^{* *}$ & - & - & -9 \\
\hline & - & - & $(0.004)$ & - & - & $(0.604)$ \\
\hline \multirow{2}{*}{$\begin{array}{l}\text { ALBA } \\
\text { members (\%) }\end{array}$} & - & - & -30 & - & - & -23 \\
\hline & - & - & $(0.202)$ & - & - & $(0.192)$ \\
\hline \multirow{2}{*}{$\begin{array}{l}\text { UNASUR } \\
\text { members }(\%)\end{array}$} & - & - & 21 & - & - & $107^{* *}$ \\
\hline & - & - & $(0.545)$ & - & - & $(0.009)$ \\
\hline Year fixed effects & Yes & Yes & Yes & Yes & Yes & Yes \\
\hline Period & $\frac{1994-}{2014}$ & $\begin{array}{l}1994- \\
2014\end{array}$ & $\begin{array}{l}1994- \\
2014\end{array}$ & $\begin{array}{l}1994 \\
2014\end{array}$ & $\begin{array}{l}1994- \\
2014\end{array}$ & $\begin{array}{l}1994- \\
2014\end{array}$ \\
\hline Pseudo $R^{2}$ & 0.15 & 0.19 & 0.21 & 0.12 & 0.13 & 0.15 \\
\hline Observations & 366 & 366 & 366 & 366 & 366 & 366 \\
\hline
\end{tabular}

P-values in parentheses.

Statistical significance: $" p<0.05 " p<0.01 \cdots p<0.001$.

Mercosur members fixed effects take into account the suspensions of Paraguay and Venezuela.

5 incorporate geographical regions fixed effects. Finally, models 3 and 6 include both geographical regions and regional organizations fixed effects. The incremental nature of the models helps to test the robustness of our findings across different sub-regions and membership in different regional organizations within Latin America.

The three models explaining mentions of 'integration' in speeches $(1,2$ and 3) confirm our expectations with regard to the regional frames presidents used alongside the term 'integration'. The findings further support our expectations regarding regime ideology and democratic performance. The stronger left a president's ideology, the more he or she used the word 'integration' in the yearly UNGA speeches. Specifically, each point to the right on the 1-7 point scale reduced the probability of the word 'integration' being used by 13-16 per cent. Independently, holding all other variables stable, the post-liberal period had a positive effect on the use of the word 'integration'. In comparison with the years prior to 2004, post-liberal regionalism increased references to 'integration' on average by 180 per cent. With regard to democracy, each one point-increase in democratic performance increased the probability that 'integration' was mentioned in a speech by approximately ten per cent.

The results on economic performance are mixed. The effect of economic growth is small and statistically insignificant, although in two of the three models higher per capita national income is associated with more frequent use of the 
word 'integration'. However, the magnitude of the effect is comparably small with a probability increase of 1-8 per cent. Nevertheless, overall we can conclude that Latin American presidents spoke about integration in favourable economic and political contexts when they belonged to the political left, and more so when their mandate fell during the post-liberal period. Above all, the term 'integration' was associated with all sub-regional framings except 'hemisphere'.

Models 4, 5 and 6 explain the use of the word 'cooperation'. In line with the results for 'integration' being used in speeches, the mentioning of 'cooperation' was strongly associated with rightist governments, the years the model of open regionalism dominated, and poorer democratic performance. With regard to regime ideology, each additional point in the seven-point left-right scale increased the probability that a president spoke about cooperation by $18-20$ per cent, depending on the model. This holds for the periods of both open and post-liberal regionalism, although the years of the Pink Tide reduced the use of the word 'cooperation' by about 75 per cent. With respect to democracy, a worsening of democratic performance increased the probability that 'cooperation' was mentioned by approximately three per cent per each point in the Polity IV scale. Lastly, the hypothesis that talk of integration and cooperation at the UNGA reflects the external security environment of states was not confirmed using the interstate disputes variable. The negative effect on mentioning 'integration' is substantive (20-44 per cent, depending on the model), but not statistically significant. Therefore, we conclude that Latin America's declaratory regionalism reflects domestic political preferences for particular types of regionalism, which depend to a large extent on political ideology. Regarding the fixed effects, in model 6, UNASUR members augmented references to 'cooperation' by 107 per cent, which is consistent with the organization's goals. However, as for the geographical regions, cooperation was reserved for references to the 'hemisphere'. The effect is statistically significant and substantive, raising the probability of using the term 'cooperation' by 31 per cent.

\section{Conclusions}

Latin America's regionalism is widely known to be strong in rhetoric but weak in substance. Regionalist discourse has created expectations that have often remained unmet, resulting thus in what Hill (1993) called a 'capabilities-expectations gap'. This article has taken a closer look at the speeches of political actors talking up expectations and asked under which conditions they are likely to do so.

Our findings suggest that Latin America's declaratory regionalism is not a uniform practice. Presidents-the region's central actors in foreign policy-making-used different frames when speaking about regionalism in order to convey their political preferences for a particular type of regional relations. Analysing the annual speeches presidents delivered at the UNGA between 1994 and 2014, we found two broad types of declaratory regionalism, one emphasizing cooperation-a more limited form of regionalism - and the other integration, which entails the pooling of sovereignty. Strictly speaking, only the latter type may be blamed for the capabilities-expectations gap, as it created expectations about a far more demanding form of regional coordination with the effect of diminishing the competences of individual states. 
Although the use of the words 'cooperation' and 'integration' in the UNGA speeches was not mutually exclusive, the contexts in which they were placed differed significantly. Generally, speaking of regional relations in terms of 'cooperation' was strongly associated with the framing of the region as the 'hemisphere'. Conversely, regionalist talk about 'integration' was most frequent when presidents referred to the South American, Central American or Latin American regions. Our analysis also identified domestic political variables that affected declaratory regionalism. Leftist presidents referred more often to 'integration' in their annual speeches, and this effect holds after controlling for the years of the Pink Tide. Indeed, this period is associated with a larger number of references to 'integration' in the speeches. The positive effect of leftist ideology on the use of the word 'integration' was stronger still when countries were more democratic and wealthier.

Our findings regarding regime ideology may not come as a surprise to many Latin Americanists, who generally agree that regionalism underwent a shift from the 1990s' open regionalism to a broader, newly energized agenda of post-liberal regionalism as leftist governments were elected across Latin America. As the term 'integration' had been deeply associated with the model of open regionalism, however, it remained unclear what post-liberal regionalism and the Pink Tide governments put on these countries' political agendas: integration, albeit including a different set of policy prescriptions, or merely cooperation with no aspiration of creating supranational governance structures? Our analysis helps clarify the debate by showing that speeches delivered during the Pink Tide had a much higher probability of including references to integration. The particular way it was envisioned surely changed, but, in essence, governments during this period generally referred to the more demanding form of regional integration. To restate, the role of leftist ideology had an independent, positive effect on the use of the word 'integration' which was significant throughout the period analysed.

Our analysis of declaratory regionalism does not allow conclusions about the reasons for Latin America's regional integration gap. Illuminating what type of regionalism was referred to and under what circumstances, the findings say nothing about actual policies. However, the analysis does take a first step in that direction, advising future research to take seriously the role of ideology in shaping ideas about different types of regionalism. The relevant literature has tended to discredit ideology as a factor influencing foreign policy-making, yet our analysis strongly suggests that the neglect may have come to the detriment of greater insights into the regional dynamics of Latin American politics.

\section{Disclosure statement}

No potential conflict of interest was reported by the author.

\section{Notes on contributors}

Nicole Jenne and Francisco Urdinez are Assistant Professors at the Pontifical Catholic University of Chile. Email: njenne@uc.cl, Ischenon@nd.edu 
Luis Schenoni is a PhD student at the University of Notre Dame and a Doctoral Affiliate at the Kellogg Institute for International Studies. All three share a common research interest in Latin American foreign policies and international relations. Email: furdinez@uc.cl

\section{ORCID}

Nicole Jenne 1 http:/ / orcid.org/0000-0001-7114-3146

Luis Leandro Schenoni $\odot$ http://orcid.org/0000-0001-6770-2136

Francisco Urdinez (1) http:// orcid.org/0000-0003-3333-478X

\section{References}

Balassa, Bela (1967) 'Trade creation and trade diversion in the European common market', The Economic Journal, 77:305, 1-21

Burges, Sean W (2015) 'Revisiting consensual hegemony: Brazilian regional leadership in question', International Politics, 52:2, 193-207

Bushnell, David (2003) El Libertador: Writings of Simón Bolivar transl Frederick H Fornoff (Oxford: Oxford University Press)

Chodor, Tom and Anthea McCarthy-Jones (2013) 'Post-Liberal Regionalism in Latin America and the Influence of Hugo Chavez', Journal of Iberian and Latin American Research, 19:2, 211-223

Corrales, Javier and Richard E Feinberg (1999) 'Regimes of cooperation in the western hemisphere: Power, interests, and intellectual traditions', International Studies Quarterly, $43: 1,1-36$

Dabène, Olivier (2009) The politics of regional integration in Latin America: Theoretical and comparative explorations (New York: Palgrave Macmillan)

Deutsch, Karl W (1957) Political community and the North Atlantic Area: international organization in the light of historical experience (Princeton, NJ: Princeton University Press)

Dominguez, Jorge (2003) Boundary disputes in Latin America (Washington, DC: United States Institute of Peace)

Dominguez, Jorge (2007) International cooperation in Latin America: the design of regional institutions by slow accretion' in Amitav Acharya and A.I. Johnston (eds) Crafting cooperation: regional international institutions in comparative perspective (Cambridge: Cambridge University Press), 83-128

Feinberg, Richard E (2006) 'Presidential mandates and ministerial institutions: Summitry of the Americas, the Organization of American States (OAS) and the Inter-American Development Bank (IDB)', The Review of International Organizations, 1:1, 69-94

Flemes, Daniel and Leslie Wehner (2015) 'Drivers of strategic contestation: the case of South America', International Politics, 52:2, 163-177

Grugel, Jean and P Riggirozzi (2007) 'The Return of the State in Argentina', International Affairs, 83:1, 87-107

Grugel, Jean and Pía Riggirozzi (2012) 'Post-neoliberalism in Latin America: rebuilding and reclaiming the state after crisis', Development and Change, 43:1, 1-21

Haas, Ernst B (1958) The uniting of Europe; political, social, and economic forces, 1950-1957 (Palo Alto: Stanford University Press)

Haas, Ernst B (1970) 'The study of regional integration: reflections on the joy and anguish of pretheorizing', International Organization, 24:04, 606-646

Hill, Christopher (1993) 'The capability-expectations gap, or conceptualizing Europe's international role', Journal of Common Market Studies, 31:3, 305-328

Hurrell, Andrew (1998) 'An emerging security community in South America?' in Emanuel Adler and M Barnett (eds) Security communities (Cambridge: Cambridge University Press), 228-264.

Inglehart, Ronald (1997) Modernization and postmodernization: cultural, economic, and political change in 43 societies (Princeton, NJ: Princeton University Press) 
Jenne, Nicole (2015) 'Bolívar Se Fue de Caracas: El Regionalismo Latinoamericano Ante La Crisis Venezolana', Boletín Del Instituto de Seguridad Internacional y Asuntos Estratégicos, CARI, 60: 14-25

Jenne, Nicole, and L. Schenoni (2015) 'Latin American declaratory regionalism, an analysis of presidential discourse (1994-2014),' RCAS Working Papers, 53: 1-16

Jones, Daniel M, Stuart A Bremer and J David Singer (1996) 'Militarized interstate disputes, 1816-1992: rationale, coding rules, and empirical patterns', Conflict Management and Peace Science, 15:2, 163-213

Kim, Soo Yeon and Bruce Russett (1996) 'The new politics of voting alignments in the united nations general assembly', International Organization, 50:04, 629-652

King, Gary (1988) 'Statistical models for political science event counts: bias in conventional procedures and evidence for the exponential poisson regression model', American Journal of Political Science, 32: 838-863

Krippendorff, Klaus (2004) Content analysis: an introduction to its methodology (Thousand Oaks: Sage)

Legler, Thomas (2013) 'Post-hegemonic regionalism and sovereignty in Latin America: optimists, skeptics, and an emerging research agenda', Contexto Internacional, 35:2, 325-352

Levitsky, Steven and Kenneth M Roberts (2013) The resurgence of the Latin American left (Baltimore, MD: JHU Press)

Lima, MRS (2013) 'Realações Interamericanas: A Nova Agenda Sul-Americana e o Brasil', Lua Nova, 42: 167-201

Malamud, Andres (2005) 'Presidential diplomacy and the institutional underpinnings of MERCOSUR: an empirical examination', Latin American Research Review, 40:1, 138-164

Malamud, Andrés (2013) 'Overlapping Regionalism, No Integration: Conceptual Issues and the Latin American Experiences', Vol. 20. EUI/RSCA Working Paper Series, EUI, Florence

Malamud, Andrés and Gian Luca Gardini (2012) 'Has regionalism peaked? the Latin American quagmire and its lessons', The International Spectator, 47:1, 116-133

Mansfield, Edward D, Helen V Milner and Jon C Pevehouse (2008) 'Democracy, veto players and the depth of regional integration', World Economy, 31:1, 67-96

Marshall, Monty, Ted Robert Gurr and Keith Jaggers (2002) Polity IV project: political regime characteristics and transitions, 1800-2014. Version P4v2013 [Computer File] (College Park, MD: Center for International Development and Conflict Management, University of Maryland), URL: <<http://Www.Cidcm.Umd.Edu/Inscr/Polity/Index.Htm >>

Martín, Félix E (2006) Militarist peace in South America: conditions for war and peace (Basingstoke, NY: Palgrave Macmillan)

Mearsheimer, John J (2010) Why leaders lie: The truth about lying in international politics (Oxford; New York: Oxford University Press)

Merke, Federico (2011) The Primary Institutions of the Latin American Regional Interstate Society. Paper presented at the IDEAS Latin America Programme, London School of Economics, London, Thursday, 27 January 2011

Merke, Federico and D Reynoso (2016) 'Dimensiones de Política Exterior En América Latina Según Juicio de Expertos: Experts' Perception of Foreign Policy Dimensions', Estudios Internacionales, 48:185, 107-130

Montecinos, Verónica (1996) 'Ceremonial regionalism, institutions and integration in the Americas', Studies In Comparative International Development, 31:2, 110-123

Moravcsik, Andrew (1993) Introduction: integrating international and domestic theories of international bargaining' in Peter B Evans, Harold Karan Jacobson, and Robert D Putnam (eds) Double-edged diplomacy: international bargaining and domestic politics (Berkeley: University of California Press), 3-42 Studies in International Political Economy 25

Murillo, MV, V Oliveros and M Vaishnav (2010) 'Electoral revolution or democratic alternation?', Latin American Research Review, 45:3, 87-114

Nye, Joseph S (1968) 'Comparative regional integration: concept and measurement', International Organization, 22:04, 855-880

O'Donnell, Guillermo A (1994) 'Delegative Democracy', Journal of Democracy, 5:1, 55-69 
Onuki, Janina, Fernando Mouron and Francisco Urdinez (2016) 'Latin American Perceptions of Regional Identity and Leadership in Comparative Perspective', Contexto internacional, $38: 1,433-465$

Onuf, Nicholas (2001) 'Speaking of Policy' in Armonk Kubalkova (ed) Foreign Policy in A Constructed World (New York: M. E. Sharpe), 77-95

Palmer, Glenn, Vito D'Orazio, Michael Kenwick and Matthew Lane (2015) 'The MID4 dataset, 2002-2010: procedures, coding rules and description'. Conflict Management and Peace Science, 32:2, 222-242

Pérez Liñan, Aníbal S (2010) Presidential impeachment and the new political instability in Latin America Cambridge Studies in Comparative Politics (Cambridge: Cambridge University Press)

Riggirozzi, Pía and Diana Tussie (eds) (2012) The rise of post-hegemonic regionalism (Dordrecht: Springer)

Rivarola Puntigliano, Andrés and José Briceño-Ruiz (eds) (2013) Resilience of regionalism in Latin America and the Caribbean: development and autonomy (New York: Palgrave Macmillan)

Rojas Aravena, Francisco (2010) 'La Comunidad de Estados Latinoamericanos y Caribeños: ¿Una Opción Viable Para Consolidar El Multilateralismo Latinoamericano?', Foreign Affairs Latinoamérica, 10:3, 1-8

Rojas Aravena, Francisco (2013) 'Regionalismo e Integración Regional' in Thomas Legler, Arturo Santa Cruz and Laura Zamudio González (eds) Introducción a Las Relaciones Internacionales: América Latina y La Política Global (Oxford: Oxford University Press), 158-171. Colección Ciencias Sociales

Sanahuja, José Antonio (2007) 'Regionalismo e Integración En América Latina: Balance y Perspectivas', Pensamiento Iberoamericano Febrero, 2007: 75-106

Sanahuja, José Antonio (2009) 'Del 'Regionalismo Abierto' Al 'Regionalismo Post-Liberal': Crisis y Cambio En La Integración Regional En América Latina y El Caribe' in Laneydi Martínez, Lázaro Peña, and Mariana Vázquez (eds) Anuario de La Integración de América Latina y El Gran Caribe (Buenos Aires: CRIES), 7:11-54

Sanahuja, José Antonio (2012) 'Regionalismo Post-Liberal y Multilateralismo En Sudamérica: El Caso de UNASUR', CRIES Anuario de Integración, 9:19-71

Schenoni, Luis (2017) 'The Argentina-Brazil Regional Power Transition', Foreign Policy Analysis

Schimmelfennig, Frank (2001) 'The community trap: liberal norms, rhetorical action, and the eastern enlargement of the European union', International Organization, 55:1, 48-62

Schmitter, Philippe (1970) 'Central American integration: spill-over, spill-around or encapsulation?', Journal of Common Market Studies, 9:1, 1-48

Schmitter, Philippe (1995) 'Change in Regime Type and Progress in International Relations' in Emanuel Adler and Beverly Crawford (eds) Progress in Post-War International Relations (New York: Columbia University Press), 89-127

Serbin, Andrés (2011) 'Regionalismo y soberanía nacional en América Latina: lecciones aprendidas y nuevos desafíos' in Manuela Mesa (ed) El mundo a la deriva: crisis y pugnas de poder (Madrid: Fundación Cultura de Paz), 137-177

Shugart, Matthew Soberg and John M. Carey (1992) Presidents and assemblies: constitutional design and electoral dynamics. (Cambridge [England]; New York: Cambridge University Press)

Simmons, Beth A (2002) 'Capacity, commitment and compliance: international law and the settlement of territorial disputes', Journal of Conflict Resolution, 46:6, 829-856

Solingen, Etel (1998) Regional orders at century's dawn: global and domestic influences on grand strategy (Princeton, NJ: Princeton University Press)

Teixeira, Carlos Gustavo Poggio (2012) Brazil, the United States, and the South American subsystem: regional politics and the absent empire (New York: Lexington Books)

Tussie, Diana (2009) 'Latin America: Constrasting motivations for regional projects', Review of International Studies, 35:1, 169-188

Voeten, Eric, Anton Strezhnev and Michael Bailey (2009) United Nations General Assembly Voting Data. Harvard Dataverse, V17.: UNF:6:05OiqHLeXMiv9Q8w8+3sVw== 
Appendix

\begin{tabular}{|c|c|c|c|c|c|c|c|c|c|c|c|c|c|c|c|c|c|c|c|}
\hline & & 1 & 2 & 3 & 4 & 5 & 6 & 7 & 8 & 9 & 10 & 11 & 12 & 13 & 14 & 15 & 16 & 17 & 18 \\
\hline 1 & References to 'integration' & 1.00 & & & & & & & & & & & & & & & & & \\
\hline 2 & References to 'cooperation' & 0.24 & 1.00 & & & & & & & & & & & & & & & & \\
\hline 3 & Economic growth & 0.07 & -0.01 & 1.00 & & & & & & & & & & & & & & & \\
\hline 4 & $\begin{array}{l}\text { President's } \\
\text { ideology }\end{array}$ & -0.03 & 0.18 & -0.07 & 1.00 & & & & & & & & & & & & & & \\
\hline 5 & Electoral year & 0.02 & 0.00 & 0.04 & 0.08 & 1.00 & & & & & & & & & & & & & \\
\hline 6 & $\begin{array}{l}\text { Democratic } \\
\text { performance }\end{array}$ & 0.12 & 0.01 & 0.00 & 0.38 & 0.11 & 1.00 & & & & & & & & & & & & \\
\hline 7 & Interstate dispute & -0.08 & -0.02 & -0.09 & 0.04 & 0.01 & -0.08 & 1.00 & & & & & & & & & & & \\
\hline 8 & $\begin{array}{l}\text { References to } \\
\text { Latin America }\end{array}$ & 0.22 & 0.13 & 0.10 & -0.12 & 0.07 & -0.04 & 0.05 & 1.00 & & & & & & & & & & \\
\hline 9 & References to South America & 0.24 & 0.10 & 0.03 & -0.16 & 0.04 & 0.01 & 0.05 & 0.21 & 1.00 & & & & & & & & & \\
\hline 10 & References to 'hemisphere' & 0.09 & 0.19 & 0.05 & 0.13 & 0.09 & 0.06 & -0.03 & 0.10 & 0.09 & 1.00 & & & & & & & & \\
\hline 11 & $\begin{array}{l}\text { References to } \\
\text { Central America }\end{array}$ & 0.15 & 0.12 & -0.04 & -0.02 & -0.06 & -0.05 & 0.02 & 0.28 & $0.05-$ & -0.03 & 1.00 & & & & & & & \\
\hline 12 & $\begin{array}{l}\text { Mercosur } \\
\text { members }\end{array}$ & 0.05 & -0.01 & -0.07 & -0.16 & 0.02 & 0.17 & -0.17 & -0.05 & 0.10 & 0.03 & -0.24 & 1.00 & & & & & & \\
\hline 13 & CAN members ${ }^{a}$ & 0.10 & 0.02 & 0.01 & 0.05 & 0.03 & 0.02 & 0.31 & 0.07 & 0.06 & 0.03 & -0.23 & -0.31 & 1.00 & & & & & \\
\hline 14 & ALBA members & 0.00 & -0.11 & 0.12 & -0.50 & -0.05 & -0.39 & 0.00 & 0.24 & $0.13-$ & -0.07 & 0.16 & -0.15 & 0.09 & 1.00 & & & & \\
\hline 15 & $\begin{array}{l}\text { UNASUR } \\
\text { members }\end{array}$ & 0.09 & 0.02 & 0.09 & -0.31 & 0.01 & 0.02 & 0.00 & 0.16 & $0.17-$ & -0.02 & -0.06 & 0.15 & 0.19 & 0.26 & 1.00 & & & \\
\hline 16 & GDP per capita & -0.07 & -0.06 & 0.09 & -0.25 & 0.02 & 0.08 & -0.14 & 0.14 & 0.09 & 0.11 & -0.07 & 0.28 & -0.26 & 0.05 & 0.44 & 1.00 & & \\
\hline 17 & Population & -0.01 & 0.05 & -0.08 & -0.06 & 0.01 & 0.04 & -0.03 & 0.02 & $0.17-$ & -0.04 & -0.15 & 0.34 & -0.07 & -0.12 & -0.06 & 0.29 & 1.00 & \\
\hline 18 & Pink Tide year & 0.01 & -0.13 & 0.25 & -0.33 & -0.02 & 0.04 & -0.16 & 0.09 & $0.08-$ & -0.08 & 0.10 & 0.00 & -0.05 & 0.32 & 0.37 & 0.37 & 0.04 & 1.00 \\
\hline
\end{tabular}

